\title{
Students' Activeness in Mathematics Learning via Zoom on Algebra Learning Material
}

\author{
Rahma Daniatun ${ }^{1}$, Abd. Qohar ${ }^{1}$, Hery Susanto ${ }^{1}$ \\ ${ }^{1}$ Universitas Negeri Malang, Indonesia \\ 凶rahmadaniatun1669@gmail.com *
}

\section{Article Information}

Submitted February 01, 2021

Revised February 25, 2021

Accepted April 01, 2021

Keywords

Algebra;

Students' activeness;

Zoom.

\section{Abstract}

This research aimed to reveal the students' activeness in mathematics learning on algebra using Zoom. This research is included in the qualitative research category with a descriptive approach. The collected data were analyzed using descriptive methods by showing the total score, percentage, or average score of each respondent's answer. The results showed that students were very active and motivated in achieving learning goals during learning via Zoom. This research implies that virtual learning is feasible to be encouraged.

\section{INTRODUCTION}

Qualified and professional teachers are required to carry out an experience-based service assignment (Hendri, 2010). They are figures that can be central figures in education to produce high-quality graduates (Kholis, 2019). The previous Minister of Education and Culture of the Republic of Indonesia, Muhadjir Effendy, emphasized that teachers who have high professionalism play a role in fulfilling the functions and roles, among others (a) as professional staff in teaching, guiding and training; (b) as a humanitarian worker to realize all human capabilities; and (c) as a welfare officer to educate people to be good citizens (Prasetya, 2018). Teachers should be capable of using a variety of learning media. They should activate the interactions among students and increase learning efficiency and effectiveness (Abdullah, 2017). A positive relationship between the use of media and learning effectiveness has been found in several empirical research. Experimental research that has been conducted found that instructional media increased student learning outcomes influenced by student self-motivation (Putri et al., 2020). Several studies have found that learning media has a direct effect on learning, for example, comic media on accounting (Irawan et al., 2019), photos and diagrams on learning motivation (Widiyanti \& Ansori, 2020), and ICT-based media, 3D media, and environmental media on the attractiveness and learning outcomes of Geography (Prasetya, 2018). A significant variety of media makes learning effective and efficient.

The world is currently facing the COVID-19 pandemic. One of the preventive efforts to break the chain of spreading, the government has issued several policies, such as social distancing and work from home (WFH). Working from home is applied to employees who work in offices, agencies, or schools. This policy influenced the work mode, including in the education sector, from the center to the regions. The learning process previously carried out in classrooms (face-to-face) is temporarily replaced by learning at home using the online system. The government finally issued a policy for the learning process through the Joint Decree (SKB)

\footnotetext{
How to cite

Daniatun, R., Qohar, A., \& Susanto, H. (2021). Students' activeness in mathematics learning via zoom on algebra 
to prohibit face-to-face learning for red-zones (COVID-19 prone area). Other areas must strictly adhere to health protocols (Kemdikbud, 2020).

To encourage students' activeness in learning mathematics on algebraic material during the COVID-19 period, the teachers need to put in the extra effort. One effort that can be applied is using appropriate media to attract students' attention and involvement. Also, the right media in the teaching and learning process can help teachers improve students' understanding. It is expected for the teaching and learning process to run well, and the students can be more active. Learning media has become an essential part of learning; even its existence cannot be separated from learning in schools (Setyorini \& Churiyah, 2016). Media has a vital role in classroom learning, affecting the quality and success of learning because learning media are tools to implement the learning activities (Widodo \& Wahyudin, 2018).

Zoom is a medium that can be used for learning during the COVID-19 pandemic. Zoom is an application that provides remote conferencing services by combining video conferencing, online meetings, chat, and mobile collaboration (Ismawati \& Prasetyo, 2020). It can accommodate 1000 participants together in one virtual meeting. This application can be downloaded for free but still functional. The features include telephone calls, webinars, presentations, and many others. This application is considered good quality because some Fortune 500 companies have used its service (Wibawanto, 2020). It has the most customers and users in the world. Zoom's daily meeting in April 2020, the participants reached 300 million. Through Zoom, teachers and students can meet virtually in the classroom. Students can learn through the learning files and videos while teachers can assess them.

Several previous studies have looked at the effectiveness of online learning on the quality of higher education in Indonesia (Mustofa et al., 2019) by increasing students' concentration, activeness, independence, and motivation (Khamparia \& Pandey, 2017; Hartanto, 2016; Waryanto, 2006; Aini et al., 2019). Web media-based learning can also improve students' learning outcomes (Sahronih et al., 2019) and numerical skills (Sidik et al., 2020). However, these studies were generally carried out for general learning subjects other than mathematics. Specific research on the use of Zoom in algebra learning is still difficult to find. Therefore, this research was directed to reveal how students are active in learning algebra using Zoom. This research aimed to investigate the students' level of activeness and their responses in algebra learning via Zoom.

\section{METHODS}

This research employed field research with a qualitative approach (Sampieri, n.d.) It is descriptive to describe the activeness of the seventh-grade students of Islamic Junior High School Hidayatullah, Sorong. The samples were determined using the purposive sampling technique. The research data were collected using three methods: 1) observing the students' activeness in learning algebra via Zoom; 2) distributing questionnaires to determine students' responses to Zoom; 3) interviewing the students about the use of Zoom in algebra learning. The interview informants were four students from six research subjects determined purposively (Palinkas et al., 2015), namely those willing to be interviewed.

The interviews were conducted via Zoom after all the lessons had ended. The interview questions were general, for example, regarding students' views on learning via Zoom and their reasons. The quantitative data from observations, questionnaires, and interviews were analyzed 
using descriptive statistic methods. This method allows the researchers to see the central tendency and the rate at which data values spread. In this research, the researchers displayed the total score, the percentage score, and the mean score. The table presentation is in the form of a descending order (highest to lowest) to facilitate data interpretation (Megharaja et al., 2018). The interpretation of students' activeness quality based on the observations' results follows the categorization proposed by Suseno, Yuwono, and Muhsetyo (Suseno et al., 2017).

Table 1. The Percentage of the Activeness Criteria

\begin{tabular}{cc}
\hline Achievement $(\mathbf{c})$ & Criteria \\
\hline $75 \%<\mathrm{c} \leq 100 \%$ & High \\
\hline $50 \%<\mathrm{c} \leq 75 \%$ & Moderate \\
\hline $26 \%<\mathrm{c} \leq 50 \%$ & Low \\
\hline $0 \% \leq \mathrm{c} \leq 25 \%$ & Poor \\
\hline
\end{tabular}

The questionnaire data are converted into a range of mean values (excellent-poor) (Akano et al., 2015)

Table 2. The Score Criteria of the Questionnaire

\begin{tabular}{lc}
\hline \multicolumn{1}{c}{ Final Score Range $(\mathrm{r})$} & Score Criteria \\
\hline $3.0<\mathrm{r} \leq 4.0$ & Excellent \\
\hline $2.0<\mathrm{r} \leq 3.0$ & High \\
\hline $1.0<\mathrm{r} \leq 2.0$ & Low \\
\hline $0.0<\mathrm{r} \leq 1.0$ & Poor \\
\hline
\end{tabular}

The qualitative data were analyzed using the inductive method by drawing conclusions based on respondents' answers during the interviews.

\section{RESULTS AND DISCUSSION}

This section presents research findings based on observations, questionnaires, and interviews. It covers students' activeness in learning. The factors strongly influenced students' activeness and students' perceptions of Zoom.

\section{The Level of Students' Activeness}

The results of students' activeness assessment in learning algebraic material via Zoom are presented in Table 1.

Table 1. Students' Activeness Scores

\begin{tabular}{|c|c|c|c|c|c|c|c|c|c|c|c|c|c|c|}
\hline \multirow{2}{*}{$\begin{array}{l}\text { Stude } \\
\text { nt }\end{array}$} & \multicolumn{12}{|c|}{ Indicators Score } & \multirow[t]{2}{*}{ Total } & \multirow{2}{*}{$\begin{array}{l}\text { Aver } \\
\text { age }\end{array}$} \\
\hline & 1 & 2 & 3 & 4 & 5 & 6 & 7 & 8 & 9 & 10 & 11 & 12 & & \\
\hline 1. & $\begin{array}{l}75 \\
* *\end{array}$ & 80 & 88 & 88 & 88 & 75 & 80 & 80 & 88 & 80 & 80 & 85 & 987 & 82.3 \\
\hline 2. & 80 & 88 & 76 & 76 & 77 & 75 & 80 & 90 & 65 & 75 & 80 & 77 & 939 & 78.3 \\
\hline 3. & 90 & 77 & 90 & 75 & 75 & 80 & 77 & 80 & 85 & 85 & 75 & 80 & 969 & 80.8 \\
\hline 4. & 82 & 78 & 87 & 80 & 80 & 80 & 75 & 75 & 70 & 74 & 80 & 85 & 946 & 78.8 \\
\hline 5. & 83 & 65 & 80 & 90 & 88 & 75 & 80 & 74 & 88 & 80 & 75 & 80 & 958 & 79.8 \\
\hline 6. & 70 & 80 & 75 & 80 & 90 & 70 & 74 & 77 & 70 & 74 & 90 & 70 & 920 & 76.7 \\
\hline Total & 480 & 468 & 496 & 489 & 498 & 455 & 466 & 476 & 466 & 468 & 480 & 477 & & \\
\hline $\begin{array}{l}\text { Avera } \\
\text { ge }\end{array}$ & 80 & 78 & 82.6 & 81.5 & 83 & 75.8 & 77.6 & 79.3 & 77.6 & 78 & 80 & 79.5 & & \\
\hline
\end{tabular}

Notes:

1. Write down the teacher's explanation,

2. Listen to the explanation/information, 
3. Work on examples of exercise questions,

4. Observe the teacher's explanation,

5. Answer the practice questions,

6. Comment the friend's answer,

7. Ask questions to the teacher,

8. Use the media,

9. Repeat the teacher's explanation,

10. Answer teacher's questions,

11. Listen to the teacher's explanation,

12. Observe the teacher's explanation.

** The entries in this column are the average value of the observations three times.

Based on Table 1, the majority of the students were categorized as very active in learning. A total of 4 students got an average score between 76-100 (80\%), while the rest were categorized as quite active with a score between 73-75 (20\%). Based on the obtained scores, all students met the minimum competency for the school's activeness, namely 66 .

This research found that almost all students were very active in learning algebraic material via Zoom. The activeness cannot be separated from the Zoom application feature, which combines video and audio viewing capabilities, presentations, recordings, transcripts, and twoway and multi-way chat (Rahma, 2019). Zoom-in learning provides ample opportunities for students to interact and communicate their ideas orally and write to the teacher and among friends (Widodo \& Wahyudin, 2018). Also, students' activeness can be related to their motivation and interest in using virtual learning media. Several studies have found that virtual learning (Zoom, Google Meet, and others) increased students' interest in learning (Prasetya, 2018), strengthens and maintains their learning motivation (Fitriyani et al., 2020); Widiyanti \& Ansori, 2020). Online learning has positive impacts on students' learning outcomes (Suhery et al., 2020).

The highest activeness was found in the fifth indicator, answering practice questions (mean score of 83), and the third indicator, which is working on sample exercise questions (mean score of 82.6). The lowest activeness was found in the sixth indicator, which comments on friends' answers (mean score of 75.8). All students were required to submit assignments for each learning session in turns. Likewise, the students were asked to summarize when the learning had been completed, thereby increasing their understanding. It is rational enough to justify that these two indicators (indicators 5 and 3) showed the highest students' activeness during learning. These two indicators can be used as references to activate students in online learning.

The low score on the commenting on friends 'answers (indicator 6) was related to the limited learning time, which affected students' focus in listening to their friends' explanations. They did not have the opportunity to comment on their friends' answers. Their concentration became a little divided when the learning time ran out. This condition is in line with Af'ida (Af'ida, 2018), who stated that the learning time affected students' learning concentration. Besides, the available study time can affect learning outcomes (Lestari, 2014). Another explanation was that some students gave many comments on other friends' answers but did not consider the time available. When the lesson had finished, many students did not have time to respond to other answers. 


\section{Students' Perceptions toward Zoom}

The data of students' responses toward Zoom in algebra learning are shown in Table 2.

Table 2. Questionnaire Responses toward Zoom Application

\begin{tabular}{cccccccccc}
\hline \multirow{2}{*}{ Response } & \multicolumn{1}{c}{ Aspects } & \multicolumn{2}{c}{ Total } & \multirow{2}{*}{ Average ** } \\
\cline { 2 - 7 } 1. & $\mathbf{1}$ & $\mathbf{2}$ & $\mathbf{3}$ & $\mathbf{4}$ & $\mathbf{5}$ & $\mathbf{6}$ & $\mathbf{7}$ & & 4.0 \\
2. & 4 & 4 & 4 & 4 & 4 & 4 & 4 & 28 & 4.0 \\
3. & 4 & 4 & 4 & 4 & 4 & 4 & 4 & 28 & 4.0 \\
4. & 4 & 4 & 4 & 4 & 4 & 4 & 4 & 28 & 4.0 \\
5. & 4 & 4 & 4 & 4 & 4 & 4 & 4 & 28 & 3.9 \\
6. & 4 & 4 & 4 & 4 & 3 & 4 & 4 & 27 & 23.7 \\
Total & 24 & 24 & 24 & 23 & 23 & 23 & 24 & & 2.8 \\
Average & 4 & 4 & 4 & 3.8 & 3.8 & 3.8 & 4 & & 2.8 \\
\hline
\end{tabular}

Description

1. Ease of use,

2. The ability to use Zoom

3. Feelings and interests,

4. Learning encouragement,

5. Easy to understand the material,

6. Easy to understand the instructions,

7. The attractiveness of the Zoom display.

Based on the calculation, the mean value for all indicators reached 3.1- 4 (excellent). It means that Zoom is appropriate to be used in learning algebra. Again, students' positive responses cannot be separated from Zoom's effectiveness in the learning process (Rahma, 2019). Students' understanding of algebraic material comes from the teacher's explanation and comes from Zoom. This result is in line with the media's role that can change the way of speaking in delivering material to one another (Capuno et al., 2019)-learning via Zoom ease the teachers to understand faster. The teachers do not need to explain the material too much because almost all students are enthusiastic during the learning process. The teachers also do not have to present too many examples of questions to students.

Based on the interview results, four out of six $(80 \%)$ students stated that they liked and enjoyed the algebra learning via Zoom. They can be more relaxed, and the learning can be more fun and lively. Meanwhile, two students (20\%) stated that they were not interested because they still felt awkward about using Zoom. It is expected that the frequent use of Zoom can reduce the awkwardness and disappear. It can be said that the students were pleased and interested in using Zoom.

\section{CONCLUSIONS}

Zoom made algebra learning efficient and effective. Students could be active during the learning process. They were active in observing and commenting on the results of other students' answers. Also, they did not hesitate to ask the teacher about various things. Furthermore, they were no longer shy about answering questions from teachers or other students during learning. Even though learning via Zoom is still newly implemented, students can still follow the lessons well and complete all the teacher's assignments in each meeting session.

This research contributes to the effectiveness of learning using virtual media such as Zoom. Zoom does not reduce students' interest and motivation. On the contrary, the students 
were very active. Therefore, virtual media can be an alternative during the pandemic and stock conditions, as long as it is carefully designed to produce maximum learning outcomes. This research was conducted with a limited scope, both in terms of sample and object of study. Thus, this research cannot produce generalized conclusions. This research can be a trigger for subsequent studies. Therefore, further research needs to be directed at similar studies with a broader sample and more diverse subjects.

\section{AUTHOR CONTRIBUTIONS STATEMENT}

RD worked as the main drafter in this research. data collection and instrument design assisted by AQ and HS.

\section{REFERENCES}

Abdullah, R. (2017). Pembelajaran dalam perspektif kreativitas guru dalam pemanfaatan media pembelajaran. Lantanida Journal, 4(1), 35-49.

Af'ida, I. (2018). Konsentrasi belajar ditinjau dari pengelolaan kelas dan waktu pembelajaran mata pelajaran akuntansi dasar pada siswa kelas X akuntansi SMK negeri 1 Salatiga tahun ajaran 2017/2018. (Doctoral dissertation, Universitas Muhammadiyah Surakarta).

Aini, Q., Dhaniarti, I., \& Khoirunisa, A. (2019). Effects of ilearning media on student learning motivation. Aptisi Transactions on Management (ATM), 3(1), 1-12.

Akano, A. O., Dixon, A. G. O., Mba, C., Barrera, E., Fregene, M. A., Nägele, T., Henkel, S., Hörmiller, I., Sauter, T., Sawodny, O., Ederer, M., Heyer, A. G., Lokko, Y., Dixon, A. G. O., Offei, S. K., Danquah, E., Fregene, M. A., Listgarten, J., Lippert, C., ... Ferguson, M. E. (2015). No 主観的健康感を中心とした在宅高齢者における 健康関連指標に関 する共分散構造分析Title. Nature Reviews Genetics, 11(1), 1-14.

Capuno, R., Revalde, H., Etcuban, J. O., Aventuna, M., Medio, G., \& Demeterio, R. A. (2019). Facilitating learning mathematics through the use of instructional media. International Electronic Journal of Mathematics Education, 15(1), 677-688.

Fitriyani, Y., Fauzi, I., \& Sari, M. Z. (2020). Motivasi belajar mahasiswa pada pembelajaran daring selama pandemik COVID-19. Profesi Pendidikan Dasar, 7(1), 121-132.

Hartanto, W. (2016). Penggunaan e-learning sebagai media pembelajaran. Jurnal Pendidikan Ekonomi, 10(1), 1-18.

Hendri, E. (2010). Guru berkualitas: Profesional dan cerdas emosi. Jurnal Saung Guru, 1(2), $1-11$.

Irawan, L., Yuliani, E., \& Januardi. (2019). Pengaruh media pembelajaran komik terhadap hasil belajar siswa akuntasi di SMK PGRI Palembang. Jurnal Neraca, 3(1), 99-107.

Ismawati, D., \& Prasetyo, I. (2020). Efektivitas pembelajaran menggunakan video zoom cloud meeting pada anak usia dini era pandemi COVID-19. Jurnal Obsesi : Jurnal Pendidikan Anak Usia Dini, 5(1), 665-675.

Kemdikbud. (2020). Penyesuaian kebijakan pembelajaran di masa pandemi. Www.Kemdikbud.Go.Id, 26. 
Khamparia, A., \& Pandey, B. (2017). Impact of interactive multimedia in e-learning technologies: role of multimedia in e-learning. Enhancing Academic Research With Knowledge Management Principles, 199-227.

Kholis, N. (2019). Teacher professionalism in Indonesia, Malaysia, and New Zealand. TARBIYA: Journal of Education in Muslim Society, 6(2), 179-196.

Lestari, I. (2014). Pengaruh waktu belajar dan minat belajar. Jurnal Formatif, 3(2), 115-125.

Megharaja, D. S., Rakshitha, H. J., \& Shwetha, K. (2018). Significance of searching and sorting in data structures. International Research Journal of Engineering and Technology, 5(4), 294-297.

Mustofa, M. I., Chodzirin, M., Sayekti, L., \& Fauzan, R. (2019). Formulasi model perkuliahan daring sebagai upaya menekan disparitas kualitas perguruan tinggi. Walisongo Journal of Information Technology, 1(2), 151-160.

Palinkas, L. A., Horwitz, S. M., Green, C. A., Wisdom, J. P., Duan, N., \& Hoagwood, K. (2015). Purposeful sampling for qualitative data collection and analysis in mixed method implementation research. Administration and Policy in Mental Health and Mental Health Services Research, 42(5), 533-544.

Prasetya, S. P. (2018). Effect of learning media variation to increase interest and learning outcomes of geography. Advances in Social Science, Education and Humanities Research, 212, 558-561.

Putri, D. K., Handayani, M., \& Akbar, Z. (2020). Pengaruh media pembelajaran dan motivasi diri terhadap keterlibatan orang tua dalam pendidikan anak. Jurnal Obsesi: Jurnal Pendidikan Anak Usia Dini, 4(2), 649-657.

Rahma, F. I. (2019). Kajian terhadap langkah-langkah pemilihan media dan implementasinya dalam pembelajaran bagi anak sekolah dasar. Jurnal Studi Islam, 14(2), 87-99.

Sahronih, S., Purwanto, A., \& Sumantri, M. S. (2019). The effect of interactive learning media on students' science learning outcomes. ACM International Conference Proceeding Series, Part F148391, 20-24.

Sampieri, R. H. (n.d.). No 主観的健康感を中心とした在宅高齢者における 健康関連指標 に関する共分散構造分析Title.

Setyorini, D., \& Churiyah, M. (2016). Increasing activeness and learning outcomes by developing borland delphi 7.0 application as instructional media. Journal of Education and Practice, 7(14), 129-140.

Sidik, G. T., Kelana, J. B., Altaftazani, D. H., \& Firdaus, A. R. (2020). The effect of macromedia flash based learning media to improve the ability to calculate of students in elementary school. PrimaryEdu - Journal of Primary Education, 4(2), 241-248.

Suhery, Putra, T., \& Jasmalinda. (2020). Studi pengaruh daring learning terhadap hasil belajar matematika kelas IV. Jurnal Inovasi Penelitian, 1(3), 1-4.

Suseno, W., Yuwono, I., \& Muhsetyo, G. (2017). Persamaan linear dua variabel dengan pembelajaran kooperatif TGT. Jurnal Pendidikan: Teori, Penelitian, Dan Pengembangan, 2(10), 1298-1307. 
Waryanto, N. H. (2006). Online learning sebagai salah satu inovasi pembelajaran. Pythagoras, 2(1), 10-23.

Wibawanto, T. (2020). Pemanfaatan video conference dalam pembelajaran tatap muka jarak jauh dalam rangka belajar dari rumah. Jurnal Teknologi Pendidikan, 1(1), 1-9.

Widiyanti, N., \& Ansori, Y. Z. (2020). Pengaruh media pembelajaran terhadap motivasi belajar siswa kelas V di SDN Ciparay I tahun ajaran 2020/2021. Prosiding Seminar Nasional Pendidikan, 2, 222-228.

Widodo, S., \& Wahyudin. (2018). Selection of learning media mathematics for junior school students. Turkish Online Journal of Educational Technology - TOJET, 17(1), 154-160. 